\title{
SOCIO-CULTURAL DYNAMICS AND ETHNOLINGUISTIC VITALITY OF SEMBIRAN BALINESE
}

\author{
Desak Putu Eka Pratiwi ${ }^{1}$, I Wayan Arka ${ }^{2}$, Asako Shiohara ${ }^{3}$ \\ Universitas Mahasaraswati Denpasar ${ }^{1}$, Australian National University (ANU)/Udayana \\ University $^{2}$, Tokyo University of Foreign Studies (TUFS) ${ }^{3}$ \\ desak.eka.pratiwi@gmail.com¹; wayanarka45@gmail.com²; ibashio@gmail.com³
}

\begin{abstract}
This paper reports our preliminary findings on the assessment of language vitality of Sembiran Balinese in the larger socio-cultural transformation of contemporary Bali. Sembiran Balinese, also known as Bali Aga, is a conservative mountain dialect of Balinese spoken by around 5,000 speakers in the Sembiran village, $30 \mathrm{~km}$ east of Singaraja northern Bali. The language and its culture reflect Bali in antiquity (Ardika, et al. 1991; Ardika, et al. 1997), with the language quite distinct from Lowland Balinese (Bali Dataran), for example in terms of its pronominal system and the absence of speech level system (Astini 1996, Sedeng 2007, Arka \& Sedeng 2018). The study is based on the data collected through questionnaires focusing on subjective views of ethno-linguistic vitality such as in-/out-group interactions and domains of language use in contemporary multilingual settings, supported by ethnographic data. The analysis makes use of the current development in the sociolinguistics of vitality, particularly the notions of ethnolinguistic vitality (Giles, et al 1977) and theories of language shift and endangerment (Grenoble \& Whaley 2006, Fishman 1991). The findings reveal that Sembiran Balinese appears to have a relatively strong linguistic vitality even though the speech community itself is a minority group in Bali.
\end{abstract}

Keywords: socio-cultural transformation, ethnolinguistic vitality, Balinese Sembiran

\begin{abstract}
Abstrak
Makalah ini memaparkan studi awal tentang vitalitas bahasa Bali Sembiran dalam transformasi sosial budaya Bali moderen. Bahasa Bali Sembiran, yang juga dikenal dengan Bali Aga, merupakan dialek bahasa Bali pegunungan konservatif yang digunakan oleh sekitar 5.000 penutur di desa Sembiran, yang berjarak $30 \mathrm{~km}$ dari kota Singaraja, Bali Utara. Bahasa dan budaya masyarakat Sembiran mencerminkan Bali pada zaman dahulu (Ardika, et al. 1991; Ardika, et al. 1997), dengan bahasa yang berbeda dari bahasa Bali Dataran, misalnya dalam hal sistem pronominal dan tidak adanya sistem kasta dalam penggunaan bahasa (Astini 1996, Sedeng 2007, Arka \& Sedeng 2018). Penelitian ini dilakukan berdasarkan data yang dikumpulkan melalui kuesioner yang berfokus pada pandangan subjektif terhadap vitalitas etnolinguistik, seperti interaksi dalam/luar kelompok dan domain penggunaan bahasa dalam masyarakat mulitilingual, yang juga didukung dengan data etnografi. Analisis data dilakukan berdasarkan perkembangan teori Sosiolingistik terkini terkait vitalitas bahasa, khususnya gagasan tentang vitalitas etnolinguistik (Giles, et al. 1977) serta teori tentang pergeseran bahasa (Grenoble \& Whaley 2006, Fishman 1991). Temuan penelitian ini menunjukkan bahwa vitalitas bahasa Bali Sembiran relatif kuat walaupun komunitas penuturnya merupakan kelompok minoritas di Bali.
\end{abstract}

Kata kunci: transformasi sosial budaya, vitalitas etnolinguistik, bahasa Bali Sembiran 


\section{INTRODUCTION}

Sembiran Balinese is spoken in the Sembiran village, the oldest village originated in the megalithic century located on the hills in the Tejakula subdistrict about $30 \mathrm{~km}$ east of the town of Singaraja. The village is unique because it is between the sea to the north and the mountains to the south. Its territory spreads from the beach up to the coastal mountain range. The village looks as if the hills were guarding the houses below. Once we enter the front side of the village, we will see houses designed in such a way towering upwards to follow the contours of the hill that looks very enchanting. Today Sembiran village hosts 5,885 inhabitants, and a large majority of the people are Hindus. However, their Hinduism is not like the Hinduism practiced by fellow Balinese in other parts of the island. The people of Sembiran village are called Bali Aga people, or Mountain Balinese.

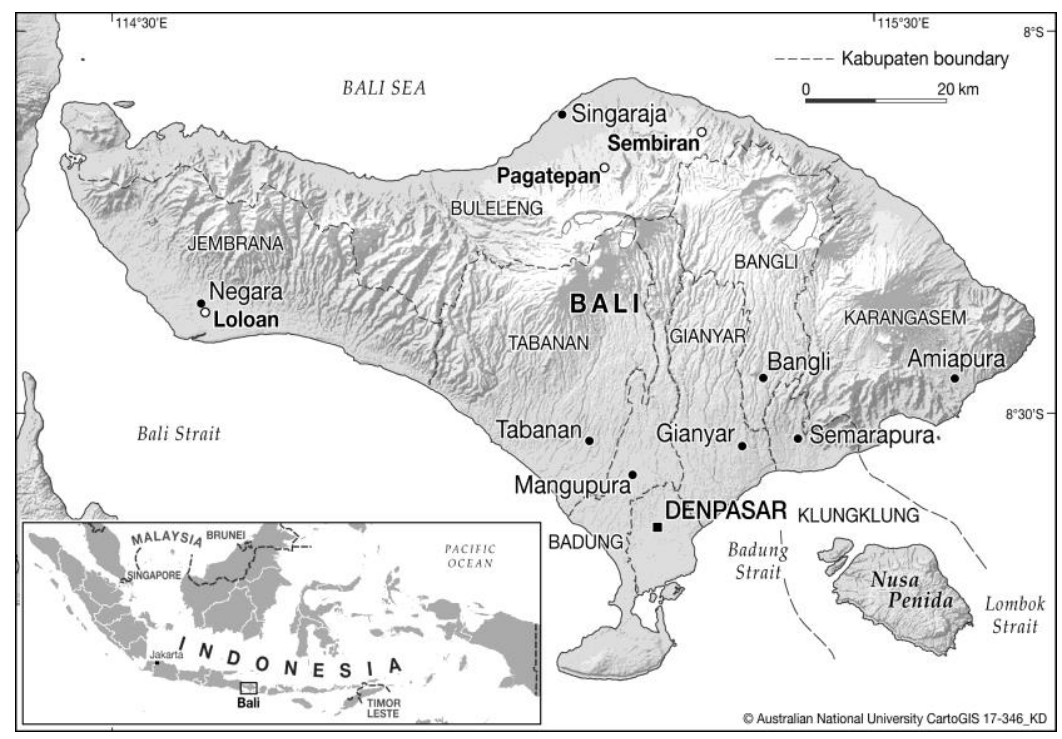

Figure 1. Map of Sembiran village in Bali

This village has been described as a survival of an ancient, somewhat mysterious culture, allegedly originating in a pre-Hindu era and still displaying "animistic" features. They were labeled (together with a couple of other mountain villages) as Bali Aga, or Old Balinese. Bali Aga people live in isolated areas in the mountains and they speak their own dialect of Balinese, which dated back thousands of years ago. They were assumed to have remained untouched by the culture of the immigrants in the $16^{\text {th }}$ century from East Java who fled to Bali after the mighty Hinduized kingdom of Majapahit collapsed due to the advent of Islam (Schaublin \& Ardika, 2008, p. 2). The Sembiran villagers speak Sembiran Balinese. The vocabulary of the language mostly comes from ancient Balinese (Bahasa Bali Kuna) and, because of this, even the villagers of Julah, its neighboring village, do not understand that language (Riemenschreider \& Schaublin, 2006, p. 9). The language is much different from the dialect of Dataran (Lowland) Balinese, the language which is used by the Balinese in any other parts of the island.

Sembiran used to be a closed community as no migration was allowed. An exception was made for Bali Aga refugees from the Kintamani area after the volcanic disaster in 1963. They were allowed to settle on a village land, but only in separate hamlets away from the main village, on the extreme southern boundaries of the territory (Barth, 1993, p. 82). 
Most Sembiran villagers are farmers. They mostly cultivate cocoa, clove, and coffee. They also breed cows, goats, pigs, and chickens. There are no tourism facilities in this village which enable the inhabitants to earn a living in tourism sector. Many families rely on financial support from their family members who work outside the village or outside the island of Bali (Riemenschreider \& Schaublin, 2006, p. 7). This shows that the Sembiran villagers also try to increase their prosperity by finding jobs outside the village or the island.

However, Sembiran today has become increasingly a progressive community due to the increasing contact with outsiders. Its inhabitants are ready to adopt and integrate innovations. Modernity influences many aspects in their lives, including their life styles and also their language. In terms of life styles, some teenagers and adults of Sembiran are able to use gadgets and they can also have access to the internet, and some of them also have social media accounts. It automatically influences their language since they tend to use Dataran Balinese when talking to people out of their group. Although the young people of Sembiran village are able to speak Dataran Balinese, the demand of using Dataran Balinese in their daily life only emerges if there are visits from non-Sembiran people (Riemenschreider \& Schaublin, 2006, pp. 7-9).

Traditional life such as local traditions, rituals, and ceremonies are still run by Sembiran villagers although technological advances have been spreading to the village. Arts and customs are still preserved in this village until now. Sacred dances are still performed in certain ceremonies both in family and community context, such as Rejang Sembiran, Baris Dadap, Baris Presi, and Baris Jojor. The dances are performed only on special days by selected groups of people. Another unique characteristic of Sembiran is their old houses, which still can be found in the village. There are also many historical heritages in this village that are believed to be more than 2,000 years old. 17 out of the 20 temples in the village have a number of Megalithic relics, as can be seen in the following pictures.
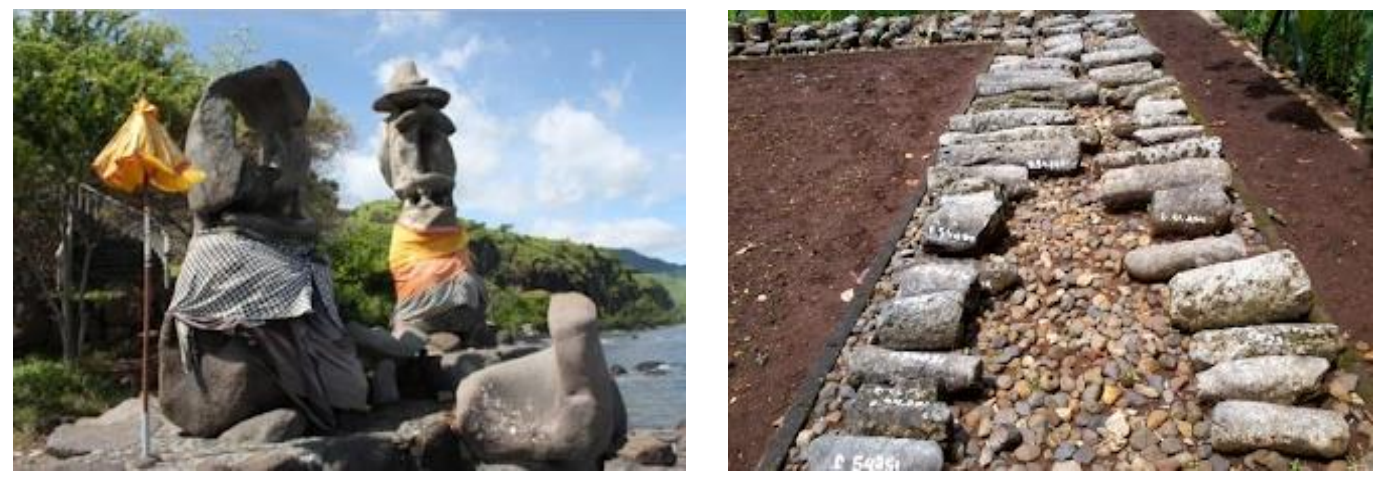

Figure 2 \& 3. Historical heritages in Sembiran

(Source: https://palm-living.com/7-old-balinese-villages-that-show-how-bali-in-the-past/)

Recent changes in the community life in Sembiran reflects the socio-cultural dynamics of contemporary Sembiran. This is of particular interest in the paper, which is further discussed in the following sections in this paper in the context of the dynamics of ethnolinguistic vitality of Sembiran Balinese. Ethnolinguistic vitality is defined as the ability "which makes a group likely to behave as a distinctive and collective entity within the intergroup setting" (Giles et al. 1977, p. 308). It involves continuing intergenerational transmission of group's language (i.e. linguistic 
vitality; cf. Pauwels 2016, p. 37) and cultural practices, sustainable demography and active social institutions, social cohesion, and emotional attachment to its collective identity.

The vitality of Sembiran Balinese is of socio-historical and linguistic significance. Sociohistorically, Sembiran Balinese is a conservative dialect of Balinese, because it is totally mutually intelligible with Dataran (Lowland) Balinese. It differs conspicuously from Dataran Balinese due to its absence of a speech level system and its archaic pronominal system (e.g. $a k u /-k u$ ' $1 \mathrm{SG}$ ' and engko/-mu '2SG') which reflect Austronesian traits that have been lost in Dataran Balinese. The extent of the difference between Sembiran and Dataran Balinese, and the precise sociohistorical-linguistic context that has led to the difference are areas of future research and beyond the scope of the present paper.

Sociolinguistically, while small in the size of its speech community $(5,885$ people), it appears that Sembiran Balinese can still maintain its healthy (ethno)linguistic vitality. The healthy vitality of Sembiran Balinese is surprising since recent intense contact with Dataran Balinese speakers has not prevented native speakers of this language from effectively transmitting it to children in their village. Language contact has been regarded as a variable that often negatively affects the wellbeing of a minority language, which will be discussed below.

\section{METHODOLOGY}

This research aims at identifying the socio-cultural dynamics and ethnolinguistic vitality of Sembiran Balinese. The data were collected by means of a combination of approaches. First, the ethnographic approach has been adopted by observing people talking in the language and participating directly with the people in communicative events. Second, the additional data was also taken from the questionnaires which give information about Sembiran Balinese vitality. We targeted 95 respondents across different age groups which represent different generations. Third, the data is further supplemented with interviews with twenty-six people of Sembiran village. The interview was done in order to get initial data about the following issues: how often they used Sembiran Balinese and to what context; how they learn and maintain Sembiran Balinese; and what are the challenges. Deep interview was also done to dig information about their sociocultural life. In this paper, we are only able to present our preliminary findings in relation to the socio-cultural dynamics and ethnolinguistic vitality of Sembiran Balinese.

\section{DISCUSSION}

The discussion will be presented in two parts: (a) Sembiran socio-cultural dynamics and (b) ethnolinguistic vitality of Sembiran Balinese.

\section{Sembiran Socio-cultural Dynamics}

Socio-cultural dynamics is a universal process. All societies at all time are subject to this process of change. Socio-cultural dynamics mean the change in the social and cultural attributes of a society. Cultural aspects denote the collectively shared values, ideas, and symbols that are associated with these groups and the pattern of social interactions existing therein.

Sembiran village is geographically isolated. It is reported to be the site of megalithic remains (Lansing, 1983, p. 120) and so it is presumably an ancient settlement site. It is located high up the spectacularly steep mountainside. Sembiran is widely named as a Bali Aga village 'Old Balinese/Mountain Balinese' and is certainly both geographically and socially more isolated 
than other parts of Bali (Barth, 1993, p. 82). Sembiran village is highly distinct from the other Balinese villages. It is famous for its (former) megaliths; its (former) practice of exposing the corpses and covering them only with leaves instead of burying or cremating them. Its egalitarian, non-caste social structure, and its language are considered uniquely antique. Anyone who enters and settles in this village has to leave all their social status or caste (if any) and comply with the customs of the village.

In this village, people are forbidden to bear any title or to trace their origin from outside the village in order to avoid perang kasta, a fight between castes. The immigrants were mostly confined to close interaction with the indigenous local population apparently on all levels of everyday life. Intermarriage between immigrant men and local women, mentioned in several oral histories, as well as economic interdependence, may have prevented the drawing of permanent boundaries between immigrants and local groups (Schaublin, 2004, p. 54).

Oral histories maintain that Sembiran was never raided and that its inhabitants never fled to another place. A few descendants of the "original" inhabitants still live in Sembiran. The socalled Bali Aga villages of Sembiran are isolated and the community is quite closed. The isolation also results in the preservation of older and different dialect of Balinese whereas low land Bali has more intense contact with outside worlds, leading to quite different varieties of Balinese. (Schaublin, 2004).

However, there is evidence that Sembiran in the olden time was in fact not totally closed off from the outside world. According to Schaublin \& Ardika (2008, pp. 3-4), the geographic location of this village which is on the border of the sea, suggests vivid interactions of all kind, attacks, fights and perhaps even wars, trading activities, the advent of men of knowledge, missionaries, immigrants, refugees and many others. There are strong indications that the villages on the North Coast were rarely culturally homogenous settlements even in the most ancient times. Among these indications are the apparently different burial practices.

In addition, the location of the village in the context of social networks, too, sociohistorically explains the internal as well the external dynamics to which Sembiran were exposed. Social network describes the structure of a particular speech community. According to Milroy (1987) social networks are composed of a "web of ties" between individuals, and the structure of a network will vary depending on the types of connections it is composed of. Social network theory (as used by sociolinguists) posits that social networks, and the interactions between members within the networks, are a driving force behind language change.

Sembiran was situated on one of the major trade routes from China, India and beyond to the Spice Islands (Maluku). Thus, far from being isolated, closed communities, these villages and their past seem to be a patchwork rather than a 2,000 years old undisturbed autochthonous culture. Schaublin and Ardika (2008) also sum up the different kinds of research that have been carried out so far in the village of Sembiran, which all give evidence of the rich cultural life in the village. Many artifacts testify to direct contact with India and China. Oral histories also tell of wars in which the villagers had to participate such as the war the famous king of Buleleng, Panji Sakti, led in Blambangan, East Java. Others tell of early contact and dealing with Islamic immigrants in the $17^{\text {th }}$ century which substantially changed the religious and social organization of the villages. The village had been continuously subject to change and it is not surprising if we consider its prominent location bordering the sea. Sembiran has been a village where people of differing origins and with different ritual practices met, producing a culture that displays corresponding traits. 
The isolation is opening up in modern Bali-Indonesia, which has resulted in more contact between Sembiran people and other Balinese. According to Schaublin \& Ardika (2008, pp. 1011), life in Sembiran has become difficult as many of the inhabitants live in poverty. Most of the fertile land along the shore, where abundant water is available, and up in the mountains, where rain regularly falls, is no longer in the hands of the core villagers. Main parts of this best agricultural land has been sold to people from other villages or to immigrants who now live high up in the mountains (Banjar Gunung Seni, Banjar Panggung), once isolated places and difficult to reach. Today, people living there cultivate cloves, coffee and cocoa - cash crops that do not grow in lower and hotter altitudes. Without the remittances from the hundreds of emigrants who left Sembiran in search for a better life elsewhere, and now live and work in other parts of Bali or in Java, life would be much harder.

Looking at their way of life, there is no public transportation in Sembiran. Most of the villagers go to work to their farms on foot. Nowadays, however, some of Sembiran people also use motorcycles like in other parts of Bali, so that some villagers also work as mechanics in small private workshops to earn money.

Unlike the areas in southern of Bali which are very popular as tourism destination, with most of local people working in tourism sector, Sembiran is far from tourism development. There are no tourism objects or tourism facilities near the village like hotels or restaurants. Although it is rich with its unique culture and traditions, this village is not (yet) popular among travelers. It has the potential to attract tourists because of the beauty of the surrounding nature, and its rich historical heritage such as its unique Balinese old houses. The cultural heritage is good for educational tourism; for instance, to introduce Bali Kuno 'Ancient Bali' for students. However, it should be noted that this village is already popular among researchers as they have come to this village to conduct various types of research and the local people seem very familiar with their research activities in this village.

Today there are other necessities and orientations that have become more important education (and the necessity to find enough money to allow children to go to school), to make a living in an area with only little developing potential, to provide the family with sufficient daily food and water, health concerns - and many others. Nowadays it is only a small percentage of the krama desa members, both males and female, who participate in the temple rituals. There are voices claiming that the money spent on elaborate rituals should better be spent on other things that promote the standard of living. In contrast to these public rituals, the life cycle rituals carried out individually still flourish, perhaps even more than before, and emigrants often return for such rituals (Schaublin \& Ardika, 2008, p. 35).

The intense contact between Sembiran Balinese and Dataran Balinese gives influence in many aspects of life of Sembiran people including their life style and language. Moreover, technological development also plays important role in Sembiran socio-cultural dynamics. Based on our observation and interview, some villagers have TV or radio so they can access the news, entertainments, music, watch movie or soap opera, which basically in Indonesian. In addition, some teenagers and adults in Sembiran village have gadgets. They are able to access the internet and have social media accounts. Consequently, they are able to communicate with their family or friends who live or work outside the village, or make friends with Dataran Balinese or even with people from outside of the island. Internet technology through mobile phones have opened up more opportunities for them to be in contact with outside groups of people, and talk in Dataran 
Balinese or Indonesian. However, they claimed that Dataran Balinese or Indonesian only used when they talked to non-Sembiran people.

\section{Ethnolinguistic Vitality of Sembiran Balinese}

There is no caste level system in Sembiran so that there is no language stratification system in Sembiran Balinese. Although technological development spreads to the village, Sembiran Balinese is relatively well preserved since Sembiran Balinese is still actively used by its native speakers across generations. Sembiran Balinese is still dominantly used by Sembiran villagers especially in the family and community context such as in banjar (sub-village unit) and temples. The elderly people in Sembiran village consistently used Sembiran Balinese to their children and grandchildren. Mostly the elderly people in Sembiran village are not able to speak Dataran Balinese or Indonesian since they have never attended formal schools, and they have not been out of their village either. Therefore, they are monolingual, actively using Sembiran Balinese in their daily life.

Our preliminary research findings reveal that Sembiran Balinese has relatively strong linguistic vitality even though the speech community itself is a minority group in Bali. The evidence comes from the speakers' positive language attitude and related socio-cultural profiles of language use in certain core domains (e.g., in domestic and public in-group communication) known in the literature to be fundamentally important for language maintenance. The data on language attitude shows high collective subjective vitality with $100 \%$ respondents saying they are proud of their language, considering Sembiran Balinese as a distinct group identity in larger intergroup contact in modern Bali. All of the respondents are highly fluent in Sembiran Balinese, committed to transmit it to their children, and highly optimistic that Sembiran Balinese will be continuously used by their next generations.

The positive attitude correlates strongly with their language behaviors indicating positive vitality. For example, Sembiran Balinese is used and acquired by children in domestic settings (100\% respondents) because older generations in the family (parents, grandparents) are all highly fluent in the language (100\% respondents). In public spheres, Sembiran Balinese is used in-group communicative settings such as socio-cultural activities in the village (100\%), daily personal interactions among them such as in the market (100\%), and outside the class at schools (90\%).

The data on the language behavior of Sembiran speakers also reveals the dynamics of diglosic language use and social-transformation in modern Bali. The Sembiran village is now no longer isolated, resulting with increasing contacts with outsiders. Increased contacts with outsiders are also due to high mobility of Sembiran (young) people; e.g. as diaspora in Denpasar for economic reasons. The positive attitude and other variables just mentioned give rise to stable multilingualism in the village, with the Sembiran people being competent multilinguals and Sembiran Balinese being a viable language for in-group communication only. Sembiran Balinese is typically not used in formal settings (e.g., in communication dealing with government officials, or in classrooms with teachers) where Indonesia is used, and other outgroup communications including in temples, in which case Dataran Balinese is often used. This pattern of language use is not surprising given the fact that Sembiran Balinese is not really mutually intelligible with Dataran Balinese, spoken by non-Sembiran Balinese people involved in such religious inter-/outgroup communication. 
While Sembiran people are undergoing socio-cultural-economic transformation in modern Bali and are increasingly multilinguals, given our findings so far, we expect that the multilingualism would not be followed by a shift towards the dominant language, either Balinese or Indonesian. If the current patterns of ethnolinguistic vitality as reported above persist, and if the Sembiran young people in diaspora still regularly come back-forth to their village, not accompanied by significantly great influx of outsiders' settling into Sembiran, then the relatively homogenous demographic make-up of the community in the village can be maintained. Such demographic make-up would be positive to the survival of Sembiran Balinese. The positive variables (i.e. stable multilingualism and demographic make-up) are, in our analysis, augmented by the ambivalent identity of the Balinese Sembiran people (100\% of the respondents): they assume as a distinct $A g a$ group identity but they also assume a common broader Balinese identity. The former is subsumed by the latter. The Balinese identity, which also has high ethnolinguistic vitality and strong culture, can in a way shield the Aga identity from negative impacts of sociocultural changes in modern multilingual Indonesia.

\section{CONCLUSION}

This paper has discussed Sembiran socio-cultural dynamics and ethnolinguistic vitality of Sembiran Balinese. Our preliminary research findings reveal that Sembiran Balinese has relatively strong linguistic vitality even though the speech community itself is a minority group in Bali. The evidence comes from the speakers' positive language attitude and related sociocultural profiles of language use in certain core domains (e.g., in domestic and public in-group communication) known in the literature to be fundamentally important for language maintenance. While Sembiran Balinese nowadays has undergone intense contact with two other major languages, Lowland Balinese and Indonesian, due to technological development and economic reasons, the contact appears to have no significant impact on the ethnolinguistic vitality of Sembiran Balinese. This conclusion is supported by our subjective vitality analysis on the basis of preliminary questionnaire data and interview.

\section{Note}

The authors would like to thank the anonymous reviewers for their very helpful comments on the earlier draft of the paper.

\section{REFERENCES}

Ardika, I W. \& Bellwood, P. (1991). Sembiran: The beginnings of Indian contact with Bali. Antiquity 65: 221-232.

Ardika, I W., Bellwood, P., Sutama, I.M. \& Yuliati, K.C. (1997). Sembiran and the first Indian contact with Bali: An update. Antiquity 71: 193-195.

Arka, I W. \& Sedeng, I N. (2018). Information structure in Sembiran Balinese. In A Crosslinguistic perspective on information structure in Austronesian language. Berlin: Language Science Press.

Astini, I.A.P. (1996). Struktur geminasi bahasa Bali dialek Sembiran. Unpublished thesis. Linguistic Graduate Program. Denpasar: Universitas Udayana. 
Barth, F. (1993). Balinese worlds. Chicago: The University of Chicago Press.

Fishman, J. (1991). Reversing language shift: Theoretical and empirical foundation of assistance to threatened languages. Clevedon, UK: Multilingual Matters Ltd.

Fishman, J. (1991). Can threatened languages be saved? Reversing language shift, revisited a $21^{\text {st }}$ century perspective. Clevedon, UK: Multilingual Matters Ltd.

Giles, H., Bourhis. R. \& Taylor, D.M. 1977. Towards a theory of language in ethnic group relations. London: Academic Press.

Grenoble, L.A. \& Whaley, L.J. (2006). Saving languages: An introduction to language revitalization. Cambridge: Cambridge University Press.

Lansing, J.S. (1983). The indianization of Bali. Journal of South and South-East Asian Studies 14 (2): 409-421.

Milroy, L. (1987). Language and social networks. New York: Blackwell.

Riemenschneider, C. \& Hauser-Schäublin, B. 2006. Yang hidup di sini, yang mati di sana: Upacara lingkaran hidup di desa Sembiran, Bali (Indonesia). Göttinger Studien zur Ethnologie, Bd. 15. Münster: LIT-Verlag.

Schaublin, B.H. 2004. Bali Aga and Islam: Ethnicity, ritual practice, and old Balinese as an anthropological construct. Indonesia, 77: 27-55.

Schaublin, B.H. \& Ardika, I W. 2008. Burials, texts and rituals. Berlin: Universitatsverlag Gottingen.

Sedeng, I N. (2007). Morfosintaksis bahasa Bali dialek Sembiran: Analisis tata bahasa peran dan acuan. Denpasar: Universitas Udayana. 